\title{
Sejarah Perkembangan Hukum Perbankan Syariah di Indonesia dan Implikasinya bagi Praktik Perbankan Nasional
}

\author{
Oleh: Abdul Ghofur Anshori
}

\begin{abstract}
Act Number 21/2008 about Sharia Banking is an act that introduce some legal institution to increase sharia banking growth with more sharia comply. For example, in this act regulate about spin-off, not only as a volountary corporate action but also as a compulsory corporate action, esp for sharia unit in conventional bank which $50 \%$ asset or have been 15 (fiveteen) years after this act operate. This corporate action have done by PT. Bank Rakyat Indonesia (Persero) "Tbk", but there are many threat, esp the operational law can be formed.According to that description we need to know about history in Indonesian sharia banking law, and also the impact from these in national banking practice. By this article, we hope that it will give an information about the regulation in sharia banking and the implementation this act in practice.
\end{abstract}

Keywords: bank syariah, sistem perbankan ganda, Unit Usaha Syariah dan pemisahan (spin-off).

\section{Pendahuluan}

Perbankan merupakan lembaga keuangan terpenting bagi pembangunan suatu negara. Hal ini disebabkan karena fungsi dari perbankan adalah sebagai lembaga intermediasi keuangan (financial intermediary institution) sebagaimana ditegaskan dalam Pasal 1 angka 2 Undang-Undang Nomor 10 Tahun 1998 tentang Perubahan Atas Undang-Undang Nomor 7 Tahun 1992 yakni bahwa Bank adalah badan usaha yang menghimpun dana dari masyarakat dalam bentuk simpanan dan menyalurkannya kepada masyarakat dalam bentuk kredit dan atau bentuk-bentuk lainnya dalam rangka meningkatkan taraf hidup rakyat banyak.

Pentingnya eksistensi dan kedudukan lembaga perbankan dimaksud membuatnya sarat mendapatkan pengaturan dari tataran konstitusi hingga

\footnotetext{
Guru Besar Fakultas Hukum UGM, Yogyakarta. Email: hk-islam@ugm.ac.id
} 
pengaturan di tataran teknis. Bank Indonesia sebagai pemegang otoritas keuangan dan perbankan telah mengeluarkan berbagai regulasi terkait dengan praktik perbankan, serta melakukan supervisi dan pengawasan agar kalangan perbankan benar-benar melaksanakan berbagai peraturan di bidang perbankan. Ketaatan institusi perbankan terhadap berbagai peraturan akan berdampak bagi peningkatan kepercayaan masyarakat terhadap bank, dimana kepercayaan merupakan ruh dari industri perbankan itu sendiri.

Di sisi lain umat Islam sebagian besar masih belum dapat menerima bank, bukan karena tidak percaya akan arti pentingnya bank bagi proses pembangunan akan tetapi karena bank-bank dimaksud mendasarkan pada sistem bunga (interest based). Bunga oleh sebagian besar umat Islam dianggap merupakan riba yang secara jelas dan tegas dilarang oleh ajaran Islam sebagaimana tertuang dalam alQuran dan Hadis Nabi Muhammad SAW.

Bagi umat Islam di Indonesia adanya pendapat bahwa bunga bank sama dengan riba dipertegas dengan keluarnya Fatwa Majelis Ulama Indonesia tentang kekharaman bunga bank yang merupakan hasil lokakarya para ulama tentang bunga bank dan perbankan di Cisarua, Bogor tanggal 19-22 Agustus 1990. Dalam lokakarya tersebut sebenarnya muncul dua pandangan yang berbeda terhadap bunga bank, yakni: (1) pendapat yang menyatakan bahwa bunga bank itu riba dan oleh karena itu hukumnya haram; (2) pendapat bahwa bunga bank bukan riba dan oleh karena itu diperbolehkan, dengan alasan "rukshah". ${ }^{1}$

Perbankan syariah sebagai elemen penting dalam hukum perbankan di Indonesia saat ini mengalami perkembangan yang pesat, dimana adanya didukung oleh terbitnya berbagai regulasi secara kelembagaan maupun berkaitan dengan kegiatan usaha. Sistem perbankan konvensional yang telah ada sebelumnya menjadi semakin lengkap dengan diintrodusirnya sistem perbankan syariah sehingga diharapkan dapat memenuhi kebutuhan semua elemen masyarakat akan jasa perbankan tanpa perlu "ragu" lagi mengenai boleh/tidaknya memakai jasa perbankan terutama jika ditinjau dari kaca mata agama. Bahwa yang menjadi kritik sistem perbankan syariah terhadap perbankan konvensional bukan dalam hal fungsinya sebagai lembaga intermediasi keuangan (financial intermediary institution), akan tetapi karena di dalam operasionalnya terdapat unsur-unsur yang dilarang, berupa unsur perjudian (maisyrir), unsur ketidakpastian/keraguan (garar), unsur bunga (interest/riba), dan unsur kebațilan. ${ }^{2}$

Bagaimana sejarah perkembangan hukum perbankan syariah di Indonesia; serta implikasi perkembangan hukum dimaksud bagi praktik perbankan syariah

${ }^{1}$ Zainul Arifin (1999), Memahami Bank Syariah: Lingkup, Peluang, dan Prospek (Jakarta: Alvabet), hal. 27.

${ }^{2}$ Abdul Ghofur Anshori (2008), "Perkembangan Hukum, Kelembagaan, dan Operasional Perbankan Syariah di Indonesia”, Makalah yang disampaikan pada Kuliah Perdana Magister Hukum Bisnis dan Kenegaraan FH UGM, Multimedia Room FH UGM Yogyakarta, tanggal 14 Juni 2008, hal. 1. 
Abdul Ghofur Anshori: Sejarah Perkembangan Hukum Perbankan Syariah ...

akan menjadi pokok bahasan dalam tulisan ini.

\section{Analisis dan Pembahasan}

\section{A. Sejarah Perkembangan Hukum Perbankan Syariah di Indonesia}

Pengertian Bank Islam (Islamic Bank) secara umum adalah bank yang pengoperasiannya mendasarkan pada prinsip syariah Islam. Istilah-istilah lain yang digunakan untuk menyebut entitas Bank Islam selain Bank Islam itu sendiri, yaitu Bank Tanpa Bunga (Interest-Free Bank), Bank Tanpa Riba (Lariba Bank), dan Bank Syariah (Sharia Bank). Indonesia secara teknis yuridis menyebut Bank Islam dengan mempergunakan istilah "Bank Syariah", atau yang secara lengkap disebut "Bank Berdasarkan Prinsip Syariah". ${ }^{3}$

Prinsip utama bank syariah terdiri dari larangan atas riba pada semua jenis transaksi; pelaksanaan aktivitas bisnis atas dasar kesetaraan (equality), keadilan (fairness) dan keterbukaan (transparency); pembentukan kemitraan yang saling menguntungkan; serta keharusan memperoleh keuntungan usaha secara halal. Bank syariah juga dituntut harus mengeluarkan dan mengadministrasikan zakat guna membantu mengembangkan lingkungan masyarakatnya. ${ }^{4}$

Pada dasarnya entitas bank syariah di Indonesia sudah dimulai sejak tahun 1983 dengan keluarnya Paket Desember 1983 (Pakdes 83) yang berisi sejumlah regulasi di bidang perbankan, dimana salah satunya ada peraturan yang memperbolehkan bank memberikan kredit dengan bunga 0\% (zero interest). Perkembagan dimaksud diikuti oleh serangkaian kebijakan di bidang perbankan oleh Menteri Keuangan Radius Prawiro yang tertuang dalam Paket Oktober 1988 (Pakto 88). Pakto 88 intinya merupakan deregulasi perbankan yang memberikan kemudahan bagi pendirian bank-bank baru, sehingga industri perbankan pada waktu itu mengalami pertumbuhan yang sangat pesat.

Baru pada tahun 1991 berdirilah Bank Muamalat Indonesia (BMI) sebagai bank umum satu-satunya yang melaksanakan kegiatan usaha berdasarkan prinsip bagi hasil. Introduksi bank berdasarkan prinsip bagi hasil dalam hukum positif adalah melalui Undang-Undang Nomor 7 Tahun 1992 tentang Perbankan dan Peraturan Pemerintah Nomor 72 Tahun 1992 tentang Bank Berdasarkan Prinsip Bagi Hasil 5 .

${ }^{3}$ Peri Umar Farouk, Sejarah Hukum Perbankan Syariah Indonesia, dikutip dari http://www.sharialearn.com/ accesed 19 November 2008.

${ }^{4}$ Institut Bankir Indonesia (2001), Konsep, Produk dan Implementasi Operasional Bank Syariah (Jakarta: Penerbit Djambatan), hal. 23.

5 Abdul Ghofur Anshori (2007), Perbankan Syariah di Indonesia (Yogyakarta: Gadjah Mada University Press), hal. 5. 
Dengan demikian sejak tahun 1992 industri perbankan Indonesia secara teknis yuridis telah mengenal istilah Bank Berdasarkan Prinsip Bagi Hasil. Namun, di sisi lain telah kita ketahui bahwa bank syariah dalam operasionalnya tidak semata-mata mendasarkan pada prinsip bagi hasil, melainkan terdapat akad-akad tradisional Islam lainnya yang dapat diimplementasikan dalam praktik bank bebas bunga dimaksud. Akad-akad tradisional Islam atau yang sering disebut sebagai prinsip syariah merupakan instrumen yang menggantikan sistem konvensional berupa bunga (riba), ketidakpastian (garar), perjudian (maisyir), dan bațil yang merupakan unsur-unsur yang dilarang dalam Islam.

Berdasarkan paradigma tersebut, serta adanya realitas empiris yang menunjukkan bahwa bank-bank konvensional banyak yang tidak sanggup bertahan di saat krisis keuangan dan moneter melanda, maka mendorong pemerintah untuk mengamandemen Undang-Undang Nomor 7 Tahun 1992. Perubahan Atas beberapa materi muatan Undang-Undang Nomor 7 Tahun 1992 dituangkan dalam Undang-Undang Nomor 10 Tahun 1998. Undang-undang inilah yang mempertegas eksistensi perbankan syariah di Indonesia.

Era Undang-Undang Nomor 10 Tahun 1998, kebijakan hukum perbankan di Indonesia menganut sistem perbankan ganda (dual banking system). Kebijakan ini intinya memberikan kesempatan bagi bank-bank umum konvensional untuk memberikan layanan syariah melalui mekanisme islamic window dengan terlebih dahulu membentuk Unit Usaha Syariah (UUS). Akibatnya pasca undang-undang ini memunculkan banyak bank konvensional yang ikut andil dalam memberikan layanan syariah kepada nasabahnya.

Pemberian layanan syariah semakin dipermudah dengan diperkenalkannya konsep office chaneling dalam Peraturan Bank Indonesia (PBI) Nomor 8/3/ $\mathrm{PBI} / 2006 .{ }^{6}$ Office chaneling intinya adalah bahwa untuk memberikan layanan syariah Bank Umum Konvensional yang sudah memiliki UUS di kantor pusatnya, tidak perlu lagi membuka Kantor Cabang/Kantor Cabang Pembantu baru melainkan cukup membuka counter syariah dalam Kantor Cabang/Kantor Cabang Pembantu konvensional. Hal ini tentu saja akan menghemat keuangan bank, karena tidak lagi memerlukan infrastruktur baru seperti gedung, alat-alat kantor, karyawan, dan teknologi informasi.

Bank Umum Syariah (BUS) selain BMI, pasca Undang-Undang Nomor 10 Tahun 1998 adalah didirikannya Bank Syariah Mandiri yang merupakan hasil akuisisi dan konversi PT. Bank Susila Bakti oleh PT. Bank Mandiri (Persero) "Tbk". Di samping itu Bank Mega juga telah melakukan proses yang sama dengan membentuk PT. Bank Syariah Mega. Sedangkan bank-bank lain, seperti PT. Bank Rakyat Indonesia (Persero) “Tbk”, PT. Bank Negara Indonesia (Persero)

${ }^{6}$ PBI tentang Perubahan Kegiatan Usaha Bank Umum Konvensional Menjadi Bank Umum Yang Melaksanakan Kegiatan Usaha Berdasarkan Prinsip Syariah Dan Pembukaan Kantor Bank Yang Melaksanakan Kegiatan Usaha Berdasarkan Prinsip Syariah Oleh Bank Umum Konvensional. 
“Tbk”, Bank Permata, dan sebagainya dalam memberikan layanan syariah masih dalam kerangka UUS.

Kegiatan usaha yang dapat dilakukan oleh BUS lebih luas dibandingkan dengan UUS dari bank konvensional. Adapun kegiatan usaha yang hanya dapat dilakukan oleh BUS, yakni: (1) menjamin penerbitan surat berharga; (2) penitipan untuk kepentingan orang lain; (3) menjadi wali amanat; (4) penyertaan modal; (5) pendiri dan pengurus dana pensiun; (6) menerbitkan, menawarkan, dan memperdagangkan surat berharga jangka panjang syariah. ${ }^{7}$

Di sisi produk, perbankan syariah mendasarkan pada sejumlah fatwa yang dikeluarkan oleh Dewan Syariah Nasional-Majelis Ulama Indonesia (DSN-MUI), antara lain yakni Fatwa No. 04/DSN-MUI/IV/2000 tentang Murabahah, Fatwa No. 07/DSN-MUI/IV/2000 tentang Pembiayaan Mudharabah, Fatwa No. 08/ DSN-MUI/IV/2000 tentang Pembiayaan Musyarakah. ${ }^{8}$

Materi muatan dari fatwa yang telah dikeluarkan oleh DSN-MUI kemudian menjadi materi muatan dalam berbagai PBI. Hal ini terlihat jelas dalam PBI No. 7/46/PBI/2005 tentang Akad Penghimpunan dan Penyaluran Dana Bagi Bank Yang Melaksanakan Kegiatan Usaha Berdasarkan Prinsip Syariah. PBI ini saat ini telah dicabut dengan PBI No. 9/19/PBI/2007 tentang Pelaksanaan Prinsip Syariah Dalam Kegiatan Penghimpunan Dana dan Penyaluran Dana serta Pelayanan Jasa Bank Syariah, sebagaimana telah diubah dengan PBI No. 10/16/PBI/2008.

Dalam PBI No. 9/19/2007 disebutkan bahwa pemenuhan Prinsip Syariah dalam kegiatan penghimpunan dana, penyaluran dana dan pelayanan jasa, dilakukan sebagai berikut:'

1. dalam kegiatan penghimpunan dana dengan mempergunakan antara lain Akad Wadi'ah dan Mudharabah;

2. dalam kegiatan peyaluran dana berupa Pembiayaan dengan mempergunakan antara lain Akad Mudharabah, Musyarakah, Murabahah, Salam, Istishna', Ijarah, Ijarah Muntahiya Bittamlik dan Qardh; dan

3. dalam kegiatan pelayanan jasa dengan mempergunakan antara lain Akad Kafalah, Hawalah, dan Sharf.

Menurut Wirdyaningsih, dkk hingga terbitnya Undang-Undang Nomor 10 Tahun 1998, Indonesia telah melewati dua tahapan pembinaan, yaitu "tahapan perkenalan" (introduction) yang ditandai dengan diberlakukannya UndangUndang Nomor 7 Tahun 1992, dan "tahapan pengakuan" (recognition) yang ditandai dengan diberlakukannya Undang-Undang Nomor 10 Tahun 1998. Tahapan yang dikehendaki berikutnya adalah "tahapan pemurnian" (purification) yang nanti akan ditandai dengan diberlakukannya undang-undang yang khusus

\footnotetext{
${ }^{7}$ Pasal 20 ayat (1) dan (2) UU No. 21 Tahun 2008.

${ }^{8}$ Lebih lanjut tentang Fatwa DSN-MUI dapat dilihat di www.sharialearn.com .

${ }^{9}$ Pasal 2 jo Pasal 3 PBI No. 9/19/PBI/2007.
} 
mengatur perbankan syariah. ${ }^{10}$

Dengan demikian "tahapan pemurnian” saat ini sudah di depan mata, karena pada tanggal 17 Juni 2008 telah disahkan Undang-Undang Perbankan Syariah yang pengundangannya dalam Lembaran Negara dilakukan tanggal 16 Juli 2008, yakni Undang-Undang Nomor 21 Tahun 2008 tentang Perbankan Syariah. Undang-undang dimaksud memperkenalkan beberapa muatan baru dan lembaga hukum baru yang ditujukan untuk menunjang pelaksanaan pembangunan nasional dalam rangka meningkatkan keadilan, kebersamaan, dan pemerataan kesejahteraan rakyat. ${ }^{11}$

Realisasi dari tujuan dimaksud, terwujud dalam fungsi bank syariah dan UUS yaitu bahwa: (1) Bank Syariah dan UUS wajib menjalankan fungsi menghimpun dan menyalurkan dana masyarakat; (2) Bank Syariah dan UUS dapat menjalankan fungsi sosial dalam bentuk baitul mal, yaitu menerima dana yang berasal dari zakat, infak, sedekah, hibah, atau dana sosial lainnya dan menyalurkannya kepada organisasi pengelola zakat; (3) Bank Syariah dan UUS dapat menghimpun dana sosial yang berasal dari wakaf uang dan menyalurkannya kepada pengelola wakaf (nazhir) sesuai dengan kehendak pemberi wakaf (wakif). ${ }^{12}$ Pelaksanaan fungsi sosial mendasarkan pada peraturan perundang-undangan terkait, yakni Undang-Undang Nomor 38 Tahun 1999 tentang Pengelolaan Zakat dan Undang-Undang Nomor 41 Tahun 2004 tentang Wakaf. Hal inilah yang menunjukkan bahwa perbankan syariah berperan sebagai financial and social intermediaries institution.

Secara kelembagaan isu baru yang diintrodusir dalam Undang-Undang Perbankan Syariah yakni ketentuan tentang pemisahan (spin-off) terhadap UUS yang terdapat dalam Bank Umum Konvensional untuk dijadikan BUS, baik secara sukarela atau karena diwajibkan dengan telah terpenuhinya persyaratan tertentu. Pemisahan adalah pemisahan usaha dari Bank menjadi dua badan usaha atau lebih, sesuai dengan ketentuan peraturan perundang-undangan.

Peraturan perundang-undangan dimaksud, yakni Undang-Undang Nomor 40 Tahun 2007 tentang Perseroan Terbatas dan peraturan pelaksanaanya, serta ketentuan khusus di bidang perbankan berupa PBI. Namun hingga saat ini ketentuan operasional dimaksud belum ada, sehingga akan menghambat pelaksanaan spin-off bagi bank yang hendak melaksanakannya, antara lain yakni PT. Bank Rakyat Indonesia (Persero) “Tbk”.

Pembentukan BUS melalui pemisahan UUS merupakan suatu terobosan dalam rangka lebih "mensyariahkan" bank syariah. Adanya BUS yang secara yuridis mandiri, akan lebih mengoptimalkan layanan jasa perbankan syariah sehingga diharapkan operasional bank syariah benar-benar memenuhi prinsip

10 Wirdyaningsih, et al. (2005), Bank dan Asuransi Islam di Indonesia (Jakarta: Kerja sama Kencana Media Group dan Fakultas Hukum Universitas Indonesia), hal. 3.

${ }^{11}$ Pasal 3 UU No. 21 Tahun 2008.

${ }^{12}$ Pasal 4 UU No. 21 Tahun 2008. 
larangan pencampuradukan antara yang halal dan yang haram.

Dalam rangka penyusunan PBI, yang materi muatannya berasal dari Fatwa Majelis Ulama Indonesia, Bank Indonesia membentuk komite perbankan syariah. Tata cara pembentukan, keanggotaan, dan tugas komite perbankan syariah nantinya akan diatur dengan PBI. ${ }^{13}$ Adanya ketentuan ini menurut hemat penulis akan memunculkan sinergi antara Dewan Syariah Nasional dengan Bank Indonesia selaku pemegang otoritas perbankan nasional.

PBI yang secara khusus merupakan peraturan pelaksana dari UndangUndang Nomor 21 Tahun 2008 tentang Perbankan Syariah dan telah diundangkan hingga saat ini yaitu: ${ }^{14}$

1. PBI No. 10/16/PBI/2008 tentang Perubahan atas PBI No. 9/19/PBI/2007 tentang Pelaksanaan Prinsip Syariah Dalam Kegiatan Penghimpunan Dana dan Penyaluran Dana Serta Pelayanan Jasa Bank Syariah.

2. PBI No. 10/17/PBI/2008 tentang Produk Bank Syariah dan Unit Usaha Syariah.

3. PBI No. 10/18/PBI/2008 tentang Restrukturisasi Pembiayaan bagi Bank Syariah.

4. PBI No. 10/23/PBI/2008 tentang Perubahan Kedua atas PBI No. 6/21/ PBI/2004 tentang Giro Wajib Minimum dalam Rupiah dan Valuta Asing bagi Bank Umum yang Melaksanakan Kegiatan Usaha Berdasarkan Prinsip Syariah.

5. PBI No. 10/24/PBI/2008 tentang Perubahan Kedua atas PBI No. 8/21/ PBI/2006 tentang Penilaian Kualitas Aktiva Bank Umum yang Melaksanakan Kegiatan Usaha Berdasarkan Prinsip Syariah.

6. PBI No. 10/32/PBI/2008 tentang Komite Perbankan Syariah.

Undang-Undang Nomor 21 Tahun 2008 juga memberikan kesempatan bagi warga negara asing dan/atau badan hukum asing untuk mendirikan atau memiliki BUS secara kemitraan dengan warga negara Indonesia dan/atau badan hukum Indonesia. ${ }^{15} \mathrm{Hal}$ ini merupakan bukti bahwa bank syariah merupakan sektor yang terbuka bagi investor asing yang bermaksud mendirikan atau memiliki BUS secara joint venture, sehingga ketentuan-ketentuan yang ada di dalam Undang-Undang Nomor 25 Tahun 2007 tentang Penanaman Modal dan peraturan pelaksanaanya perlu diperhatikan dan dilaksanakan oleh pihak terkait.

Berdasarkan Statistik Perbankan Syariah (Islamic Banking Statistics) yang dikeluarkan oleh Bank Indonesia bulan November 2008 Jaringan Kantor Networking terdiri dari 4 (empat) Bank Umum Syariah, yakni PT. Bank Muamalat Indonesia, PT. Bank Syariah Mandiri, PT. Bank Syariah Mega Indonesia, dan PT. Bank Syariah BRI. Unit Usaha Syariah (UUS) bank konvensional yang

\footnotetext{
${ }^{13}$ Pasal 26 UU No. 21 Tahun 2008.

${ }^{14}$ www.bi.go.id, accesed 20 November 2008.

15 Pasal 9 ayat (1) huruf b UU No. 21 Tahun 2008.
} 
memberikan layanan syariah berjumlah 27 dan Bank Perkreditan Rakyat Syariah berjumlah 128.16

Melihat perkembangan hukum yang menopang industri perbankan syariah di Indonesia berlangsung begitu pesat, maka akan menimbulkan implikasi baik yang positif maupun negatif. Untuk itu, maka perlu ada kesiapan dari pelaku bisnis di bidang perbankan untuk menyiapkan sumber daya manusia yang mempunyai kompetensi dan pemahaman terkait dengan aspek-aspek perbankan syariah menyangkut aspek fikih maupun aspek hukum positif yang mengitarinya, serta kecermatan dalam pengembangan produk perbankan syariah. Implikasi dalam setiap perkembangan hukum perbankan syariah bagi praktik perbankan nasional akan dibahas lebih lanjut dalam uraian di bawah ini.

\section{B. Implikasi Perkembangan Hukum di Bidang Perbankan Syariah Bagi Praktik Perbankan Nasional}

Hukum yang termanifestasi antara lain dalam peraturan perundangundangan pada dasarnya menurut Roscoe Pound merupakan alat rekayasa sosial kemasyarakatan (law as a tool of social engineering). Dalam penyusunan produk hukum hendaknya mendasarkan pada suatu paradigma tertentu yang sesuai dengan kepribadian bangsa (volkgeist), serta tetap memperhatikan realitas empiris yang terjadi di tengah-tengah masyarakat.

Produk hukum paradigmatis akan mampu bertahan lama, sehingga penyusunannya memerlukan kajian akademis secara mendalam. Munculnya suatu produk hukum yang paradigmatis atau hanya karena didorong oleh kepentingan sesaat yang reaktif dapat kita lihat dari implikasi produk hukum dimaksud ketika diberlakukan efektif di masyarakat. Bagaimana implikasi produk hukum di bidang perbankan, khususnya perbankan syariah pada setiap tahapannya dapat dikemukakan sebagai berikut:

\section{Tahapan Perkenalan (Introduction)}

Tahap perkenalan (introduction) sebagaimana dikemukakan di atas dimulai tahun 1992, yakni dengan diundangkannya Undang-Undang Nomor 7 Tahun 1992 tentang Perbankan. Undang-undang inilah yang memperkenalkan bank berdasarkan prinsip bagi hasil, yang kemudian didukung dengan Peraturan Pemerintah Nomor 72 Tahun 1992 tentang Bank Berdasarkan Prinsip Bagi Hasil.

Pasal 1 angka 12 Undang-Undang Nomor 7 Tahun 1992 menyebutkan bahwa kredit adalah penyediaan uang atau tagihan yang dapat dipersamakan dengan itu, berdasarkan persetujuan atau kesepakatan pinjam-meminjam antara

16 Statistik Perbankan Syariah, http://www.bi.go.id/web/id/Statistik/Statistik+ Perbankan+Syariah/, accesed 23 Januari 2008. 
bank dengan pihak lain yang mewajibkan pihak peminjam untuk melunasi hutangnya setelah jangka waktu tertentu dengan jumlah bunga, imbalan atau pembagian hasil keuntungan. Ketentuan ini menunjukkan bahwa di Indonesia telah memperkenalkan bentuk kredit yang tidak mendasarkan pada sistem bunga, melainkan bentuk lain berupa imbalan dan bagi hasil.

Pada era ini bank hanya diperbolehkan melaksanakan satu jenis kegiatan secara konvensional atau secara bagi hasil. Hal ini terlihat jelas pada Pasal 1 PP No. 72 Tahun 1992 yang menyatakan bahwa Bank berdasarkan prinsip bagi hasil adalah Bank Umum atau Bank Perkreditan Rakyat yang melakukan kegiatan usaha semata-mata berdasarkan prinsip bagi hasil.

Ketentuan dimaksud lebih dipertegas pada Pasal 6 PP No. 72 Tahun 1992, yaitu sebagai berikut:

a. Bank Umum atau Bank Perkreditan Rakyat yang kegiatan usahanya sematamata berdasarkan prinsip bagi hasil, tidak diperkenankan melakukan kegiatan usaha yang tidak berdasarkan prinsip bagi hasil.

b. Bank Umum atau Bank Perkreditan Rakyat yang kegiatan usahanya tidak berdasarkan prinsip bagi hasil tidak diperkenankan melakukan kegiatan usaha yang berdasarkan prinsip bagi hasil.

Implikasi pengaturan yang demikian, yakni bahwa layanan syariah hanya dapat dilaksanakan oleh Bank Umum atau Bank Perkreditan Rakyat yang sematamata melaksanakan kegiatan usahanya berdasarkan prinsip syariah, atau dalam hal ini secara teknis yuridis dikenal dengan Bank Berdasarkan Prinsip Bagi Hasil. Bank yang telah ada dan melaksanakan kegiatan usaha berdasarkan prinsip syariah pada waktu itu, yakni Bank Muamalat Indonesia (BMI).

BMI mempunyai visi untuk menjadi bank syariah utama di Indonesia, dominan di pasar spiritual, dikagumi di pasar rasional. Sementara misi BMI yaitu menjadi ROLE MODEL Lembaga Keuangan Syariah dunia dengan penekanan pada semangat kewirausahaan, keunggulan manajemen dan orientasi investasi yang inovatif untuk memaksimumkan nilai bagi stakeholder. ${ }^{17}$

Hal ini menunjukkan bahwa era Undang-Undang Nomor 7 Tahun 1992, perkembangan industri perbankan syariah di Indonesia belum menggembirakan. Layanan syariah yang diberikan hanya terbatas ditinjau dari lembaga yang memberi layanan maupun produk-produknya. Dengan kata lain dapat ditegaskan bahwa sektor hukum belum cukup berkontribusi dalam perkembangan bank syariah di Indonesia.

\section{Tahapan Pengakuan (Recognition)}

Tahap pengakuan ditandai dengan diundangkannya Undang-Undang Nomor 10 Tahun 1998 tentang Perubahan Atas Undang-Undang Nomor 7

${ }^{17}$ Anonim, Visi dan Misi Bank Muamalat, dikutip dari http://www.muamalatbank. com/profil/vismis.asp accessed 21 November 2008. 
Tahun 1992 tentang Perbankan. Keluarnya undang-undang ini pada hakikatnya merupakan respon pemerintah karena adanya krisis keuangan dan moneter yang berdampak serius bagi perbankan di Indonesia. Harapannya akan mengembalikan kepercayaan masyarakat terhadap perbankan, misalnya ditandai dengan diintrodusirnya Lembaga Penjamin Simpanan.

Lembaga Penjamin Simpanan adalah badan hukum yang menyelenggarakan kegiatan penjaminan atas simpanan Nasabah Penyimpan, melalui skim asuransi, dana penyangga, atau skim lainnya. ${ }^{18}$ Lebih lanjut melalui Pasal 37B ayat (1) ditegaskan bahwa setiap bank wajib menjamin dana masyarakat yang disimpan pada bank yang bersangkutan.

Terkait dengan perbankan syariah, Undang-Undang Nomor 10 Tahun 1998 telah memberikan pengakuan secara tegas terhadap eksistensinya. Hal ini nampak pada pengertian/definisi Bank Umum dan Bank Perkreditan Rakyat. Bank Umum adalah bank yang melaksanakan kegiatan usaha secara konvensional dan atau berdasarkan Prinsip Syariah yang dalam kegiatannya memberikan jasa dalam lalu lintas pembayaran. Sementara Bank Perkreditan Rakyat adalah bank yang melaksanakan kegiatan usaha secara konvensional atau berdasarkan Prinsip Syariah yang dalam kegiatannya tidak memberikan jasa dalam lalu lintas pembayaran. ${ }^{19}$

Dari pengertian tersebut menunjukkan bahwa Indonesia menganut kebijakan sistem perbankan ganda (dual bangking system) sebagaimana telah dikemukakan di atas. Pasal dimaksud juga menunjukkan bahwa hanya bank umum yang boleh melaksakan kegiatan usaha secara konvensional dan syariah, sedangkan bank pekreditan rakyat hal demikian tidak diperbolehkan. BPR hanya boleh memilih melakukan kegiatan usaha secara konvensional atau secara syariah.

Adanya kebijakan yang membolehkan bank umum konvensional untuk memberikan layanan syariah dengan terlebih dahulu membentuk UUS di kantor pusatnya menyebabkan perkembangan bank syariah di Indonesia berlangsung lebih cepat daripada sebelumnya. Bank-bank umum konvensional pasca UndangUndang Nomor 10 Tahun 1998 mulai memberikan layanan syariah melalui mekanisme Islamic Window, antara lain yaitu PT. Bank Rakyat Indonesia (Persero) "Tbk", PT. Bank Negara Indonesia 1946 (Persero) "Tbk", dan PT. Bank Permata.

Kemudahan dalam rangka pemberian layanan syariah, selain diintrodusirnya konsep Islamic Window juga karena diperbolehkannya Kantor Cabang/Kantor Cabang Pembantu memberikan layanan syariah melalui mekanisme office chaneling. Kedua lembaga hukum inilah yang menurut hemat penulis berimplikasi bagi perkembangan yang signifikan layanan jasa bank syariah di Indonesia. Hal

\footnotetext{
${ }^{18}$ Pasal 1 angka 24 UU No. 10 Tahun 1998.

${ }^{19}$ Pasal 1 angka (3) dan (4) UU No. 10 Tahun 1998.
} 
mana juga didukung oleh peraturan operasionalnya, antara lain yakni PBI No. 8/3/PBI/2006 dan PBI No. 9/19/PBI/2007 beserta perubahannya sebagaimana tersebut di atas.

Munculnya UUPT, yakni Undang-Undang Nomor 1 Tahun 1995 tentang Perseroan Terbatas sebagaimana yang telah diganti dengan Undang-Undang Nomor 40 Tahun 2007 tentang Perseroan Terbatas juga berkontribusi bagi perkembangan bank syariah, khususnya dalam rangka pembentukan BUS, sebagai bank yang murni syariah. Hal ini terlihat pada ketentuan mengenai penggabungan, peleburan, pengambilalihan, dan pemisahan sebuah legal entity. Pengaturan mengenai hal dimaksud di samping tunduk pada UUPT, secara khusus mengacu pada peraturan perundang-undangan di bidang perbankan sebagai lex specialis.

Praktik yang terjadi di era Undang-Undang Nomor 10 Tahun 1998, yakni mulai terbentuknya BUS-BUS baru dengan jalan pengambilalihan (akuisisi) yang diikuti dengan perubahan (konversi) kegiatan usaha dari konvensional menjadi syariah. Contoh konkritnya yakni terjadinya akuisisi terhadap PT. Bank Susila Bakti oleh PT. Bank Mandiri (Persero) "Tbk" yang kemudian dikonversi menjadi Bank Syariah Mandiri. Hal serupa juga dilakukan oleh PT. Bank Mega yang membeli bank konvensional untuk kemudian dikonversi menjadi syariah.

Dengan demikian dapat ditegaskan bahwa pada tahap pengakuan terbukti secara empiris perkembangan dan pertumbuhan perbankan syariah sudah cukup menggembirakan. Namun mengingat adanya karakteristik yang berbeda antara bank konvensional dan bank syariah, maka sementara kalangan berpendapat mengenai perlunya undang-undang yang khusus mengatur perbankan syariah. Hal ini juga didorong oleh adanya keinginan masyarakat agar praktik perbankan syariah lebih optimal, khususnya ditinjau dari ketaatan bank terhadap prinsipprinsip syariah (sharia compliance).

\section{Tahapan Pemurnian (Purification)}

Tahap pemurnian merupakan tahap yang terpenting, karena banyak anggapan bahwa praktik perbankan syariah yang berjalan hingga saat ini untuk beberapa hal masih belum sesuai dengan prinsip syariah. Diundangkannya Undang-Undang Nomor 21 Tahun 2008 tentang Perbankan Syariah hakikatnya dilatar belakangi oleh niatan untuk meningkatkan ketaatan bank syariah terhadap prinsip-prinsip syariah sebagaimana tertuang dalam al-Quran dan al-Hadis. Niatan ini sejalan dengan Visi Pengembangan Perbankan Syariah Nasional yaitu terwujudnya sistem perbankan syariah yang sehat, kuat, dan istiqamah terhadap prinsip syariah dalam kerangka keadilan, kemaslahatan dan keseimbangan, guna mencapai masyarakat yang sejahtera secara material dan spiritual (falah) ${ }^{20}$

${ }^{20}$ Harisman (2006), "Peranan Bank Indonesia Dalam Pengembangan Perbankan Syariah”. Makalah pada Seminar Nasional Reformulasi Sistem Ekonomi Syariah \& Legislasi Nasional, Semarang, 6-8 Juni 2006, BPHN- Departemen Hukum \& HAM 
Dalam rangka kepentingan pemurnian dimaksud, Undang-Undang Nomor 21 Tahun 2008 tentang Perbankan Syariah hadir memberikan pengaturan terkait dengan kelembagaan dan produk perbankan syariah. Adapun pengaturan yang akan dibahas pada bagian ini adalah tentang Komite Perbankan Syariah dan pemisahan (spin-off) UUS dari Bank Umum Konvensional dan implikasinya bagi perbankan syariah ke depan.

Pemisahan adalah pemisahan usaha dari satu Bank menjadi dua badan usaha atau lebih, sesuai dengan ketentuan peraturan perundang-undangan. ${ }^{21}$ Pemisahan sebagaimana telah disebutkan di atas dapat dilakukan secara sukarela atau menjadi sesuatu yang wajib dalam hal UUS bank konvensional telah memenuhi persyaratan tertentu. Pemisahan secara sukarela terhadap UUS sedang dilaksanakan oleh PT. Bank Rakyat Indonesia (Persero) "Tbk". Proses yang dilaksanakan mengalami kendala, karena hingga saat ini belum ada peraturan operasionalnya baik dalam bentuk Peraturan Pemerintah sebagaimana diamanatkan oleh Undang-Undang Nomor 40 Tahun 2007 maupun Peraturan Bank Indonesia.

Pemisahan (spin-off) yang merupakan kewajiban di atur dalam Ketentuan Peralihan Pasal 68 Undang-Undang Nomor 21 Tahun 2008, yakni:

a. Dalam hal Bank Umum Konvensional memiliki UUS yang nilai asetnya telah mencapai paling sedikit 50\% (lima puluh persen) dari total nilai aset bank induknya atau 15 (lima belas) tahun sejak berlakunya Undang-Undang ini, maka Bank Umum Konvensional dimaksud wajib melakukan Pemisahan UUS tersebut menjadi Bank Umum Syariah.

b. Ketentuan lebih lanjut mengenai Pemisahan dan sanksi bagi Bank Umum Konvensional yang tidak melakukan Pemisahan sebagaimana dimaksud pada ayat (1) diatur dengan Peraturan Bank Indonesia.

Berdasarkan ketentuan dimaksud dapat kita simpulkan bahwa pada hakikatnya arah perkembangan sektor perbankan di Indonesia adalah menuju sistem perbankan syariah yang lebih berkualitas dari sisi pengelolaan dan ketaatan terhadap syariah. Hal ini juga diperkuat oleh ketentuan sebagaimana tertuang dalam Pasal 5 ayat (6), (7), dan (8) yang intinya menyatakan bahwa Bank Konnvensional hanya dapat mengubah kegiatan usahanya berdasarkan Prinsip Syariah dengan izin Bank Indonesia. Lebih lanjut disebutkan bahwa Bank Umum Syariah dan Bank Pembiayaan Rakyat Syariah tidak dapat dikonversi menjadi Bank yang konvensional.

Komite Perbankan Syariah sebagaimana yang diamanatkan oleh UndangUndang Nomor 21 Tahun 2008, telah mendapatkan peraturan operasionalnya berupa PBI No. 10/32/PBI/2008 tentang Komite Perbankan Syariah. Pasal 1 angka 1 PBI dimaksud menyebutkan bahwa Komite Perbankan Syariah, yang selanjutnya disebut Komite adalah forum yang beranggotakan para ahli di bidang

RI, p.7.

${ }^{21}$ Pasal 1 angka 32 UU No. 21 Tahun 2008. 
syariah muamalah dan/atau ahli ekonomi, ahli keuangan, dan ahli perbankan, yang bertugas membantu Bank Indonesia dalam mengimplementasikan fatwa Majelis Ulama Indonesia menjadi ketentuan yang akan dituangkan ke dalam Peraturan Bank Indonesia.

Adapun tugas Komite secara spesifik adalah membantu Bank Indonesia dalam: (a) menafsirkan fatwa MUI yang terkait dengan perbankan syariah; (b) memberikan masukan dalam rangka implementasi ke dalam Peraturan Bank Indonesia; (c) melakukan pengembangan industri perbankan syariah. Hasil pelaksanaan tugas dimaksud akan disampaikan kepada Bank Indonesia dalam bentuk rekomendasi. ${ }^{22}$

Adanya keharusan untuk spin-off dan Komite Perbankan Syariah menunjukkan bahwa telah ada upaya secara hukum untuk menciptakan semakin banyak BUS, sehingga operasionalnya akan lebih optimal dan lebih mendekati kepada pelaksanaan prinsip syariah yang benar-benar sesuai. Dengan demikian visi Bank Indonesia sebagaimana dikemukakan di atas akan dapat terlaksana, berikut misinya yakni mewujudkan iklim yang kondusif untuk pengembangan perbankan syariah yang kompetitif, efisien dan memenuhi prinsip kehati-hatian, yang mampu mendukung sektor riil melalui kegiatan berbasis bagi hasil dan transaksi riil dalam rangka mendorong pertumbuhan ekonomi nasional.

\section{Penutup}

Berdasarkan pada pemaparan di atas dapat ditarik kesimpulan, bahwa secara historis telah ada upaya hukum untuk memajukan perbankan syariah di Indonesia. Pada setiap tahapan sebagaimana dimaksud pelan tapi pasti, Indonesia sebagai negara dengan penduduk muslim terbesar di dunia akan memiliki sistem perbankan syariah yang kuat dari sisi permodalan dengan tetap melaksanakan prinsip-prinsip syariah. Adapun langkah terpenting yang harus dilakukan saat ini adalah perlunya sosialisasi dan edukasi kepada masyarakat tentang berbagai aspek perbankan syariah dan bagi pemerintah perlu segera meralisasikan terbitnya peraturan operasional untuk melaksanakan Undang-Undang Nomor 21 Tahun 2008 tentang Perbankan Syariah. Dengan demikian apa yang menjadi harapan dan cita-cita, serta tujuan pembangunan nasional berupa terciptanya masyarakat adil dan makmur berdasarkan demokrasi ekonomi yang berasaskan pada nilai keadilan, kebersamaan, pemerataan, dan kemanfaatan yang sesuai dengan prinsip syariah akan terlaksana dengan sukses.

\section{DAFTAR PUSTAKA}

Abdul Ghofur Anshori (2007), Perbankan Syariah di Indonesia. Yogyakarta:

\footnotetext{
${ }^{22}$ Pasal 5 PBI No. 10/32/PBI/2008.
} 
Gadjah Mada University Press.

(2008), "Perkembangan Hukum, Kelembagaan, dan Operasional

Perbankan Syariah di Indonesia", Makalah yang disampaikan pada Kuliah

Perdana Magister Hukum Bisnis dan Kenegaraan FH UGM, Multimedia

Room FH UGM Yogyakarta, tanggal 14 Juni 2008.

Anonim, Statistik Perbankan Syariah, dikutip dari http://www.bi.go.id/web/id/

Statistik/Statistik+Perbankan+Syariah/, accesed 23 Januari 2008.

---------, Visi dan Misi Bank Muamalat, dikutip dari http://www.muamalatbank. com/profil/vismis.asp accessed 21 November 2008.

Harisman (2006), "Peranan Bank Indonesia Dalam Pengembangan Perbankan

Syariah", Makalah pada Seminar Nasional Reformulasi Sistem Ekonomi

Syariah \& Legislasi Nasional, Semarang, 6-8 Juni 2006, BPHN-

Departemen Hukum \& HAM RI.

http://www.bi.go.id

http://www.sharialearn.com

Institut Bankir Indonesia (2001), Konsep, Produk dan Implementasi Operasional

Bank Syariah. Jakarta: Penerbit Djambatan.

Peraturan Bank Indonesia Nomor 10/32/PBI/2008 tentang Komite Perbankan Syariah.

Peraturan Bank Indonesia Nomor 8/3/PBI/2006 tentang Perubahan Kegiatan

Usaha Bank Umum Konvensional Menjadi Bank Umum Yang Melaksanakan

Kegiatan Usaha Berdasarkan Prinsip Syariah Dan Pembukaan Kantor Bank

Yang Melaksanakan Kegiatan Usaha Berdasarkan Prinsip Syariah Oleh

Bank Umum Konvensional.

Peraturan Pemerintah Nomor 72 Tahun 1992 tentang Bank Berdasarkan Prinsip

Bagi Hasil.

Peraturan Perundang-undangan.

Peri Umar Farouk, Sejarah Hukum Perbankan Syariah Indonesia, dikutip dari http://www.sharialearn.com/. accesed 19 November 2008.

Undang-Undang Nomor 10 Tahun 1998 tentang Perubahan Atas Undang-

Undang Nomor 7 Tahun 1992 tentang Perbankan.

Undang-Undang Nomor 21 Tahun 2008 tentang Perbankan Syariah.

Undang-Undang Nomor 7 Tahun 1992 tentang Perbankan.

Wirdyaningsih, et al. (2005), Bank dan Asuransi Islam di Indonesia. Jakarta:

Kerja sama Kencana Media Group dan Fakultas Hukum Universitas Indonesia.

Zainul Arifin (1999), Memahami Bank Syariah: Lingkup, Peluang, dan Prospek. Jakarta: Alvabet. 